University of Vermont

UVM ScholarWorks

Rubenstein School of Environment and Natural Rubenstein School of Environment and Natural Resources Faculty Publications

4-1-2011

\title{
Historical carbon emissions and uptake from the agricultural frontier of the Brazilian Amazon
}

\author{
Gillian L. Galford \\ Ecosystems Center \\ Jerry M. Melillo \\ Ecosystems Center \\ David W. Kicklighter \\ Ecosystems Center \\ John F. Mustard \\ Brown University \\ Timothy W. Cronin \\ Ecosystems Center
}

See next page for additional authors

Follow this and additional works at: https://scholarworks.uvm.edu/rsfac

Part of the Agriculture Commons, Climate Commons, and the Sustainability Commons

\section{Recommended Citation}

Galford GL, Melillo JM, Kicklighter DW, Mustard JF, Cronin TW, Cerri CE, Cerri CC. Historical carbon emissions and uptake from the agricultural frontier of the Brazilian Amazon. Ecological Applications. 2011 Apr;21(3):750-63.

This Article is brought to you for free and open access by the Rubenstein School of Environment and Natural Resources at UVM ScholarWorks. It has been accepted for inclusion in Rubenstein School of Environment and Natural Resources Faculty Publications by an authorized administrator of UVM ScholarWorks. For more information, please contact scholarworks@uvm.edu. 
Authors

Gillian L. Galford, Jerry M. Melillo, David W. Kicklighter, John F. Mustard, Timothy W. Cronin, Carlos E.P. Cerri, and Carlos C. Cerri 


\title{
Historical carbon emissions and uptake from the agricultural frontier of the Brazilian Amazon
}

\author{
Gillian L. Galford, ${ }^{1,2,5}$ Jerry M. Melillo, ${ }^{1}$ David W. Kicklighter, ${ }^{1}$ John F. Mustard, ${ }^{2}$ Timothy W. Cronin, ${ }^{1,6}$ \\ Carlos E. P. Cerri, ${ }^{3}$ and Carlos C. Cerrit ${ }^{4}$ \\ ${ }^{1}$ The Ecosystems Center, Marine Biological Laboratory, Woods Hole, Massachusetts 02543 USA \\ ${ }^{2}$ Geological Sciences, Brown University, Providence, Rhode Island 02912 USA \\ ${ }^{3}$ Escola Superior de Agricultura "Luiz de Queiroz," Universidade de São Paulo, Piracicaba, Brazil \\ ${ }^{4}$ Centro de Energia Nuclear na Agricultura, Universidade de São Paulo, Piracicaba, Brazil
}

\begin{abstract}
Tropical ecosystems play a large and complex role in the global carbon cycle. Clearing of natural ecosystems for agriculture leads to large pulses of $\mathrm{CO}_{2}$ to the atmosphere from terrestrial biomass. Concurrently, the remaining intact ecosystems, especially tropical forests, may be sequestering a large amount of carbon from the atmosphere in response to global environmental changes including climate changes and an increase in atmospheric $\mathrm{CO}_{2}$. Here we use an approach that integrates census-based historical land use reconstructions, remote-sensing-based contemporary land use change analyses, and simulation modeling of terrestrial biogeochemistry to estimate the net carbon balance over the period 1901-2006 for the state of Mato Grosso, Brazil, which is one of the most rapidly changing agricultural frontiers in the world. By the end of this period, we estimate that of the state's $925225 \mathrm{~km}^{2}$, $221092 \mathrm{~km}^{2}$ have been converted to pastures and $89533 \mathrm{~km}^{2}$ have been converted to croplands, with forest-to-pasture conversions being the dominant land use trajectory but with recent transitions to croplands increasing rapidly in the last decade. These conversions have led to a cumulative release of $4.8 \mathrm{Pg} \mathrm{C}$ to the atmosphere, with $\sim 80 \%$ from forest clearing and $20 \%$ from the clearing of cerrado. Over the same period, we estimate that the residual undisturbed ecosystems accumulated $0.3 \mathrm{Pg} \mathrm{C}$ in response to $\mathrm{CO}_{2}$ fertilization. Therefore, the net emissions of carbon from Mato Grosso over this period were $4.5 \mathrm{Pg} \mathrm{C}$. Net carbon emissions from Mato Grosso since 2000 averaged $146 \mathrm{Tg}$ C/yr, on the order of Brazil's fossil fuel emissions during this period. These emissions were associated with the expansion of croplands to grow soybeans. While alternative management regimes in croplands, including tillage, fertilization, and cropping patterns promote carbon storage in ecosystems, they remain a small portion of the net carbon balance for the region. This detailed accounting of a region's carbon balance is the type of foundation analysis needed by the new United Nations Collaborative Programmme for Reducing Emissions from Deforestation and Forest Degradation (REDD).
\end{abstract}

Key words: Amazon; $\mathrm{CO}_{2}$ fertilization; carbon emissions; cerrado; crops; global warming; land cover and land use change; Mato Grosso, Brazil; pasture; soils; terrestrial ecosystems model; United Nations Collaborative Programmme for Reducing Emissions from Deforestation and Forest Degradation (REDD).

\section{INTRODUCTION}

The role of the tropics in the global carbon cycle is still an unsettled question (Schimel 2007). Two recent analyses based on inverse models have led to different conclusions about how the tropics are functioning in the global carbon cycle. The first study, by Jacobsen et al. (2007), has found a strong tropical source that implies there are large emissions from land use change,

Manuscript received 23 October 2009; revised 30 June 2010; accepted 27 July 2010. Corresponding Editor: A. R. Townsend.

5 Present address: The Earth Institute at Columbia University, Geosciences 102A, P.O. Box 1000, Palisades, New York 10964 USA. E-mail: gg2405@columbia.edu

${ }^{6}$ Present address: Earth, Atmospheric, and Planetary Sciences, Massachusetts Institute of Technology, Cambridge, Massachusetts 02139 USA. primarily due to deforestation, and suggest that mechanisms, such as $\mathrm{CO}_{2}$ fertilization, that stimulate carbon uptake in the remaining tropical forests are relatively unimportant. The second study, by Stephens et al. (2007), suggests that the uptake and storage of carbon in the tropics balances deforestation emissions.

Research on carbon emissions from land use change in the tropics indicates that the amount is large, but uncertain (Ramankutty et al. 2007). Canadell et al. (2007) estimate tropical land use emissions for this decade to be $1.5 \pm 0.5 \mathrm{Pg} \mathrm{C}$ (mean $\pm \mathrm{SD})$. The current method used for estimating carbon emissions from tropical deforestation tracks changes in the fate of carbon pools after cutting, often using simple response functions to describe carbon losses similar to those initially developed by Houghton et al. (1983). The areas deforested are derived from either national scale 
assessments (FAO 2006) or satellite analyses (INPE 2009a). The resulting estimates are highly sensitive to vegetation biomass at the time of cutting as well as the accuracy of the estimates of the area cleared.

The Amazon region has long been recognized for its role in global ecosystem services, such as water cycling and carbon storage, but rapid development of agriculture now threatens carbon sinks and its net impact on carbon cycling is rapidly changing. The history of intensive research on the role of Amazon ecosystems in the carbon cycle spans several decades. Much of what we understand about the net uptake or release of carbon by intact tropical forests and cerrado areas is based on site-level studies using a range of methods including the eddy flux technique and repeated measures of aboveground biomass on inventory plots. For forests and cerrado of the Amazon Basin, eddy flux methods generally show net carbon uptake (e.g., Grace et al. 1995, Malhi et al. 1998, Miranda et al. 2008), although one study has shown net carbon release from an oldgrowth forest in the central Amazon (Saleska et al. 2003). A synthesis of Amazon forest survey data by Phillips et al. (1998) has shown forests functioning as net carbon sinks. This has been confirmed by a recent analysis of forest monitoring data from permanent plots in the Amazon by Laurance et al. (2009), who found an acceleration of tree growth over several decades that robustly supports a hypothesis of carbon accumulation from $\mathrm{CO}_{2}$ fertilization.

In addition to plot-level studies of ecosystems processes, accurate satellite-based regional information on the location and temporal dynamics of land cover and land use changes is needed for regional carbon budget estimates to reduce uncertainty on the role of the tropics in the global carbon budget and, in particular, to elucidate where land use change emissions are greater than natural carbon sinks. One powerful approach for estimating regional carbon budgets involves the coupling of state-of-the-art ecosystem models with land cover and land use information derived from remote-sensing products. Because of its frequent overpasses and the availability of the data it generates, the Moderate Resolution Imaging Spectrometer (MODIS) is an important source of information for these studies (Justice 1998). This has been especially true for the Brazilian Amazon during the Large-Scale BiosphereAtmosphere (LBA) study, a long-term, internationally supported research program led by the Brazilian government to understand the regional biological, chemical, and physical functions of the Amazon and alterations due to land use and climate changes in the context of sustainable development and global climate. For example, DeFries et al. (2008) and Morton et al. (2008) have used a process-based biogeochemistry model, DECAF, coupled with fire data derived from MODIS to estimate carbon emissions from biomass burning in the state of Mato Grosso in the southern
Amazon. Potter et al. (2009) used MODIS observations of vegetation together with the CASA model, another biogeochemistry model, to simulate regional patterns of productivity and net carbon fluxes in intact forests of the Amazon in response to climate variability. These studies, and others like them in the Amazon, separately explain patterns in carbon dynamics from natural vegetation and carbon losses from land use transitions. An important next step in understanding changes in the carbon cycle in the Brazilian Amazon is to study combined changes in land cover, land use, land management, and changing environmental conditions. While remote sensing imagery is useful for studying recent carbon dynamics in this region, the influence of land use history beyond the period of remote sensing observations on these carbon dynamics also needs to be examined.

Here we explore the combined role of this complex set of controls on regional-scale carbon emissions from the state of Mato Grosso, home of Brazil's fastest growing agricultural frontier (Hansen et al. 2008, INPE 2009b, Galford et al. 2010). We quantify land use emissions in the context of changes in the carbon budget of the state's remaining intact natural ecosystems, the forests and the cerrado. Beyond previous studies focusing on natural systems or emissions from conversions, we integrate the landscape dynamics of natural vegetation, land use change, and management using explicit land use data derived from remote sensing in a process-based ecosystems model. The objectives of this study are: (1) to understand the role of historical land use change on carbon emissions in the frontier of the Brazilian Amazon and (2) to understand the role of intact natural systems in the regional greenhouse gas budget including the loss of carbon sequestration potential due to land use change.

\section{Methods}

We develop a 105-year integrated land use data set and use it with the process-based Terrestrial Ecosystem Model (TEM) to calculate the impacts of land use change on regional-scale carbon emissions from the rapidly developing agricultural frontier of the state of Mato Grosso, Brazil, within the context of other changing environmental factors. The long time series allows us to separate land use change and climate effects. We assess how land management of croplands (fertilizer application, tillage, and cropping practices) may influence storage of soil organic matter. The simulations occur at a moderate resolution $\left(1 \mathrm{~km}^{2}\right)$ that is relevant to regional management of carbon, such as in assessing carbon credits. Below, we describe the study area, the TEM along with model modifications implemented for this study, and the development of land use and other data sets used by TEM. We also describe the simulation experiments we carried out to examine the relative importance of land use changes, different land management options, and $\mathrm{CO}_{2}$ fertilization on carbon dynamics of Mato Grosso. 


\section{Study area}

Mato Grosso is a large state $\left(925225 \mathrm{~km}^{2}\right)$ in the southern Brazilian Amazon. The natural vegetation of Mato Grosso is a mix of cerrado (savanna) and tropical forest (Fig. 1; Castro and Kauffman 1998) that experiences a humid tropical climate with a short dry season (June-September). For the purposes of this study, we identify six natural vegetation types (Table 1) simplified from the data presented by Mello (2007). Mello (2007) provided us with vegetation data from the Mato Grosso state government (SEPLAN-MT 2007), a coordinated study of physical, biological, and socioeconomic conditions. The cerrado, considered a global biodiversity hot spot (Myers et al. 2000), varies in community structure from tree-rich areas (cerradão) to grass- (campo limpo) and shrub-dominated areas (cerrado stricto sensu). Across Brazil, two-thirds of the cerrado's native extent has been converted to agriculture and much of the remaining intact cerrado is in Mato Grosso (Klink and Machado 2005, Conservation International 2008).

Beginning in the 1940s, throughout Mato Grosso, large-scale clearing of natural vegetation for pasture and cropland continues with little transition back to secondary growth (Rudel et al. 2005, Morton et al. 2006). Today a complex set of transitions is occurring in the region, including the clearing of natural vegetation for both pastures and croplands and the replacement of pastures to grow crops, primarily soybeans. A recent analysis reports that the reversion of cleared land to secondary growth is rare (Morton et al. 2006).

Pastures are currently the dominant land use type in this region, but cropland area is rapidly increasing and brings with it a number of important management decisions related to cropping patterns, fertilizer use, and tillage. In an effort to increase production, some farmers in the region are changing from single (typically soybean) to double cropping (typically soybean followed by corn) in a growing season, enabled by the use of fertilizers in the double cropping system (Keys and McConnell 2005, Fundação Agrisus 2006). In this region, there are three types of tillage patterns used: no tillage, conservation tillage, and conventional tillage. Conservation tillage is a rotational program of roughly three years with no tillage and conventional tillage using deep disking plows in the fourth year.

\section{Model description}

For this study, we simulate monthly terrestrial carbon and nitrogen dynamics using a version of the processbased Terrestrial Ecosystem Model (TEM, Felzer et al. 2004) that has been modified to better incorporate the effects of land management observed in Mato Grosso. As described in Felzer et al. (2004), the exchange of carbon dioxide between terrestrial ecosystems and the atmosphere depends on both ecosystem metabolism, as influenced by local environmental conditions, and land management practices. The uptake of atmospheric carbon dioxide during photosynthesis by plants is simulated as gross primary production (GPP) and is influenced by atmospheric carbon dioxide and ozone concentrations, photosynthetically active radiation, air temperature, evapotranspiration, soil available nitrogen, and canopy stature. Carbon dioxide is returned to the atmosphere from respiration of both autotrophs and heterotrophs. Autotrophic respiration by plants is dependent upon the amount of vegetation biomass, air temperature, and GPP. Heterotrophic respiration is dominated by microbial respiration, which is associated with the decomposition of organic matter and is influenced by the amount and $\mathrm{C}: \mathrm{N}$ ratio of soil organic matter, air temperature, and soil moisture. During the conversion of natural lands to agriculture, some of the carbon in vegetation biomass is assumed to be lost as emissions to the atmosphere from human-induced fires and the rest of the vegetation biomass is partitioned among slash, 10-year, and 100-year wood product pools. The slash is added to the soil organic pool, where it is assumed to decompose at the same rate as soil organic matter, whereas the woody product pools are assumed to decompose linearly. For land areas converted to row crop agriculture, we assume that all slash that could hinder the mechanized tilling and planting of fields is removed through continued windrowing and burning to improve the accessibility and use of farm machinery. As a result, no slash is left behind in these areas to decompose. For tropical forests converted to pasture, we assume that $33 \%$ of the vegetation biomass is left as slash. In cerrado and cerradão areas, we assume $50 \%$ of the vegetation biomass is left as slash during conversion to pasture. These assumptions are consistent with the $100 \%$ combustion completeness for cropland and 50$90 \%$ combustion completeness for pastures reported by Morton et al. (2008). The harvest of crops converts $40 \%$ of the crop biomass to agricultural product pools with the remaining biomass added to soil organic matter. The agricultural pools are assumed to be consumed or decomposed linearly within a year of harvest. Additional details of these land use change dynamics may be found elsewhere (McGuire et al. 2001, Tian et al. 2003, Felzer et al. 2004).

In Felzer et al. (2004), the timing of the planting and harvesting of crops is simulated based on growingdegree-days. For this study, we prescribe the dates of crop planting and harvests based on whether a field is classified in the land use data set as a single or double crop. For areas that grow a single crop, we assume that the crop is planted in November and harvested in March. For areas of double cropping, we assume that the first crop is planted in October and harvested in January and that the second crop is planted in February and harvested in June. We further assume that the second crop of double-cropped areas is optimally fertilized. No fertilization occurs in single-cropped areas or of the first crop of double-cropped areas and we assume that there is there is no net loss of nitrogen, so 


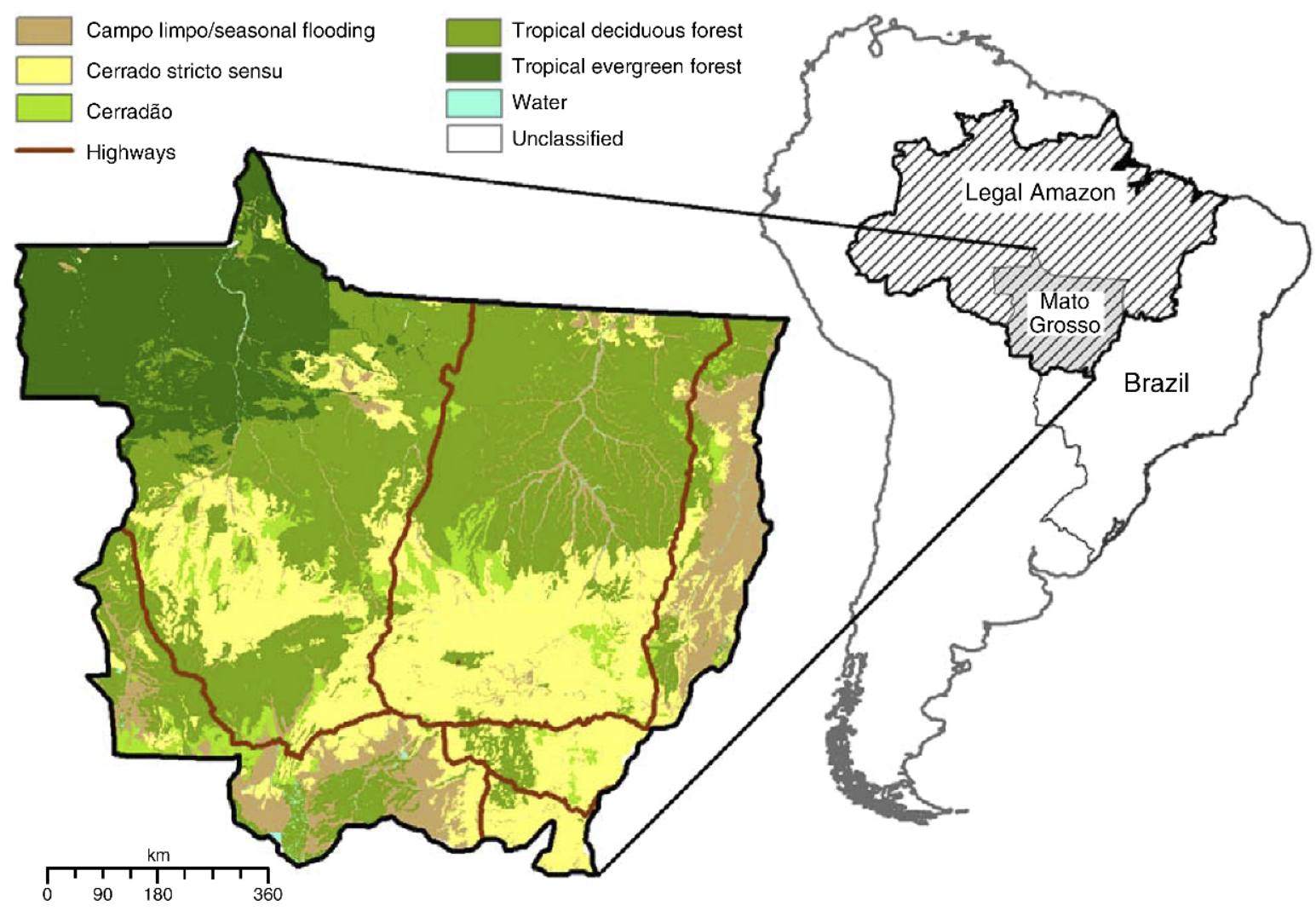

FIg. 1. Mato Grosso study area in Brazil, shown with potential natural vegetation classes (after Mello [2007] and derived from state government records [SEPLAN-MT 2007]).

the single crop or first crop of double-cropped areas acts as a nitrogen-fixing crop, such as soy.

In addition to prescribed planting and harvest dates, we also modified TEM to account for the effects of tillage on soil organic carbon stocks. In previous model applications, no-till practices have been assumed to occur in all croplands. To better account for the effects of tillage on carbon dynamics, we assume in this study that tillage doubles the decomposition rate of soil organic carbon because mixing of the soil profile and the breakup of soil aggregates exposes more carbon to oxidation than would happen in undisturbed soils (Balesdent et al. 2000). Tillage occurs every fourth year in a conservation tillage regime, so we simulate the tillage effect on decomposition once every four years and assume no-till conditions in the intervening years.

Since large areas of Mato Grosso have historically been converted for pastures rather than row-crop agriculture, we added algorithms to TEM to consider the influence of grazers on pasture biogeochemistry. In a pasture, grazers are assumed by TEM to consume $5 \%$ of the standing vegetation biomass every month as forage. This is a conservative estimate of sustainable stocking rate likened to pasture productivity, as estimated by TEM. Of the forage consumed, $83 \%$ of the carbon is respired back to the atmosphere and $17 \%$ is transferred to the soil organic carbon pool as manure. For the corresponding nitrogen in forage, $50 \%$ is transferred to the soil organic nitrogen pool as manure and $50 \%$ is transferred to the soil available nitrogen pool as urine. No additional fertilization of pastures is assumed to occur.

Thus, the calculation of net carbon exchange (NCE) between a terrestrial ecosystem and the atmosphere is as follows:

$$
\begin{aligned}
\mathrm{NCE} & =\mathrm{GPP}-R_{\mathrm{A}}-R_{\mathrm{H}}-E_{\mathrm{F}}-E_{\mathrm{P}} \\
R_{\mathrm{H}} & =R_{\mathrm{M}}+R_{\mathrm{G}} \\
E_{\mathrm{P}} & =E_{\mathrm{A}}+E_{10}+E_{100}
\end{aligned}
$$

where the variables are: autotrophic respiration $\left(R_{\mathrm{A}}\right)$, heterotrophic respiration $\left(R_{\mathrm{H}}\right)$, microbial respiration $\left(R_{\mathrm{M}}\right)$, emissions from fires associated with land-clearing $\left(E_{\mathrm{F}}\right), 10$-year and 100-year woody product pools $\left(E_{10}\right.$ and $E_{100}$, respectively), and agricultural product pools $\left(E_{\mathrm{A}}\right)$. A positive NCE indicates a net carbon sink, while a negative NCE indicates a carbon source.

The TEM is calibrated to data on carbon and nitrogen stocks and fluxes at intensively studied field sites (Raich et al. 1991, McGuire et al. 1992). For this study, we assume that the natural land cover of Mato Grosso can be represented by six dominant vegetation 
TABLE 1. Potential vegetation types, areal extent in Mato Grosso (Brazil), average aboveground biomass (in 1901), and the main species represented in each land cover (Mello 2007).

\begin{tabular}{|c|c|c|c|}
\hline Potential natural vegetation & Area $\left(\mathrm{km}^{2}\right)$ & $\begin{array}{c}\text { Average } \\
\text { aboveground } \\
\text { biomass } \\
\left(10^{6} \mathrm{~g} / \mathrm{ha}\right)\end{array}$ & Main species \\
\hline Tropical evergreen forests & 137670 & 241 & $\begin{array}{l}\text { Bertholletia excelsa, Parkia pendula, Swietenia } \\
\text { macrophylla, Virola } \mathrm{sp} ., \text { Astronium nelson-rosae, } \\
\text { Hymenaea } \text { sp., Caryocar villosum, Bertholletia } \\
\text { excelsa, Euterpe oleracea, Theobroma } \mathrm{cf} . \\
\text { subincanum, Theobroma } \mathrm{sp} ., \text { Iriartea } \mathrm{sp} ., \text { Attalea } \\
\text { maripa, Euterpe precatoria, Oenocarpus } \mathrm{sp} .\end{array}$ \\
\hline Tropical deciduous forests & 371876 & 234 & $\begin{array}{l}\text { Cedrela fissilis, Aspidosperma sp., Myroxylon } \\
\text { peruiferum, Chorisia speciosa, Zanthoxylum } \\
\text { riedelianum, Apeiba tibourbou, Tabebuia roseo-alba, } \\
\text { T. serratifolia, T. impetiginosa, Pseudobombax } \\
\text { longiflorum and P. tomentosum, Astronium } \\
\text { fraxinifolium, Anadenanthera macrocarpa and A. } \\
\text { falcata, Myracrodruon urundeuva, Acrocomia } \\
\text { sclerocarpa, Orbignia speciosa }\end{array}$ \\
\hline Riparian forests & 38602 & 123 & Inga sp., Ficus sp., Talauma ovata, Xylopia emarginata \\
\hline $\begin{array}{l}\text { Cerrado stricto sensu (savanna; } \\
20-50 \% \text { canopy cover) }\end{array}$ & 264572 & 47 & $\begin{array}{l}\text { Hymenaea stigonocarpa, Tabebuia caraiba, Annona } \\
\text { coriacea, Caryocar brasiliensis, Hancornia speciosa, } \\
\text { Davilla elliptica, Salvertia convallariaeodora, } \\
\text { Curatella americana, Kielmeyera coriacea, Qualea } \\
\text { sp., Byrsonima sp. }\end{array}$ \\
\hline Cerradão (dense savanna) & 41191 & 46 & $\begin{array}{l}\text { Pterodon pubescens, Bowdichia virgilioides, Hymenaea } \\
\text { courbaril, Magonia pubescens, Qualea } \mathrm{sp} ., \\
\text { Kielmeyera coriacea, Emmotum nitens, Machaerium } \\
\text { sp., Dalbergia sp. }\end{array}$ \\
\hline Campo limpo (savanna grassland) & 65738 & 16 & $\begin{array}{l}\text { Anacardium humile, Annona dioica, Dimorphandra } \\
\text { mollis, Alibertia sp., Solanum lycocarpum, Salvertia } \\
\text { convallariaeodora }\end{array}$ \\
\hline Other (water, unclassified) & 5576 & & \\
\hline
\end{tabular}

types: tropical evergreen forests, tropical deciduous forests, riparian forests, cerradão, cerrado stricto sensu, and campo limpo. For tropical evergreen forests, tropical deciduous forests, and riparian forests, we use the TEM parameterizations (McGuire et al. 1992) appropriate for tropical evergreen forests, but we assume the other vegetation types represent a mixture of mesic trees, xeromorphic trees and shrubs, and grasses (Table 2). For mesic trees, we also use the TEM parameterizations associated with tropical evergreen forests, but we use the TEM parameterizations associated with xeromorphic forests and woodlands for xeromorphic trees and shrubs and the grassland parameterizations for grasses.

\section{Input data}

To develop regional estimates of carbon and nitrogen stocks and fluxes, the TEM needs spatially explicit data for elevation, soil texture, land cover, climate, and atmospheric chemistry (Table 3 ). To meet these data input needs, we developed a series of data sets at a spatial resolution of $1 \times 1 \mathrm{~km}$. For elevation, we use the TerrainBase version 1.1 data set from the National Geophysical Data Center (NGDC 1994). For soil texture, we use data provided by Batjes et al. (2004). To capture the effects of land use change and climate change on terrestrial carbon dynamics, we developed spatially explicit time series data sets at the $1 \times 1 \mathrm{~km}$ spatial resolution to prescribe changes in land cover, climate, and atmospheric chemistry data.

Land use data sets.-We used two approaches over different time periods to develop a time series data set of historical land use change from 1901 to 2006 (see Appendix). For the period 1901 to 2001, we combined information from census estimates (SIDRA 2009a) and annual crop statistics (SIDRA 2009b) with the distribution patterns of pasture, single crops, and double crops determined from remote sensing imagery for the year 2001 (Morton et al. 2006, 2010, Galford et al. 2010). For the period between 2001 and 2006, we use the changes in distribution patterns of pastures, single crops, and double crops as determined from remote sensing imagery (Morton et al. 2006, 2010, Galford et al. 2010).

TABLE 2. Modeled compositions of land cover types in Mato Grosso.

\begin{tabular}{lccc}
\hline \hline Land cover type & $\begin{array}{c}\text { Xesic } \\
\text { trees (\%) }\end{array}$ & $\begin{array}{c}\text { Xeromorphic } \\
\text { trees and } \\
\text { shrubs (\%) }\end{array}$ & $\begin{array}{c}\text { Grass } \\
(\%)\end{array}$ \\
\hline Tropical evergreen forests & 100 & 0 & 0 \\
Tropical deciduous forests & 100 & 0 & 0 \\
Riparian forests & 100 & 0 & 0 \\
Cerrado stricto sensu & 10 & 60 & 30 \\
Cerradão & 70 & 30 & 0 \\
Campo limpo & 0 & 20 & 80 \\
\hline
\end{tabular}


TABLE 3. Driving data sets for the terrestrial ecosystems model (TEM).

\begin{tabular}{|c|c|c|}
\hline $\begin{array}{l}\text { Driving } \\
\text { data set }\end{array}$ & $\begin{array}{l}\text { Temporal } \\
\text { resolution }\end{array}$ & Data source \\
\hline $\mathrm{CO}_{2}$ & annual & Etheridge et al. (1996), Keeling et al. (2005) \\
\hline Cloudiness & monthly & CRU (New et al. [2002], Mitchell et al. [2004]) \\
\hline Ozone & monthly & Felzer et al. (2005) \\
\hline Precipitation & monthly & $\begin{array}{l}\text { CRU (New et al. [2002], Mitchell et al. [2004]); NCAR/ } \\
\text { NCEP (Kalnay et al. [1996]) }\end{array}$ \\
\hline Temperature & monthly & $\begin{array}{l}\text { CRU (New et al. [2002], Mitchell et al. [2004]); NCAR/ } \\
\text { NCEP (Kalnay et al. [1996]) }\end{array}$ \\
\hline Soil texture & $\mathrm{N} / \mathrm{A}$ & SOTER (Batjes et al. [2004]) \\
\hline
\end{tabular}

Notes: Abbreviations are: CRU, Climatic Research Unit; NCAR/NCEP, National Center for Atmospheric Research/National Center for Environmental Protection; SOTER, Soil and Terrain Database Programme.

Climate and atmospheric chemistry data sets.-The version of TEM used in this study requires spatially explicit data for three climate variables (air temperature, precipitation, cloudiness) and one atmospheric-chemistry variable (ozone) at a monthly time step. In addition, the model uses a time series of annual atmospheric $\mathrm{CO}_{2}$ concentrations based on the ice core record of Etheridge et al. (1996) and flask measurements at the Mauna Loa Observatory in Hawaii (Keeling et al. 2005). Mean surface air temperature, precipitation, and cloudiness were obtained for the period 1901-2000 from data sets produced by the Climate Research Unit (CRU) of the University of East Anglia (New et al. 2002, Mitchell et al. 2004). The global ozone data set is described in Felzer et al. (2005). The data sets normally exist at a spatial resolution of $0.5 \times 0.5$ degrees and are thus down-sampled to the $1-\mathrm{km}$ grid used in this study such that all $1-\mathrm{km}$ grid cells contained within a much larger $0.5 \times 0.5$ degree grid cell simply use the value of a climate driver from the larger grid cell. Because sharp climate gradients generally do not occur in the state of Mato Grosso and continuous long-term observations are not readily available, we believe this to be an adequate treatment. For the period 2001-2006, which is not covered by the CRU data set, we use baseline climatological averages (baseline period 1948-2000) for cloudiness and use a delta ratio approach to blend temperature and precipitation from the CRU and
NCAR/NCEP reanalysis (1948-2006) products. Within the NCAR/NCEP reanalysis data set, temperature differences and precipitation ratios are calculated for each month in the period 2001-2006 relative to the 1948-2000 average value for the corresponding calendar month. These differences (temperature) and ratios (precipitation) are then added to or multiplied by, respectively, the 1948-2000 average value of temperature (precipitation) from the CRU data set to obtain the blended value.

\section{Design of simulation experiments}

Besides developing regional estimates of carbon stocks and fluxes, our simulation approach also allows us to explore the relative importance of different environmental factors influencing terrestrial carbon dynamics in Mato Grosso and the potential impacts of different land management options. After conducting a simulation that best represents historical conditions in Mato Grosso (S1 in Table 4) to estimate historical carbon dynamics, we then conducted six additional simulations to examine the effects on carbon dynamics of land use change, $\mathrm{CO}_{2}$ fertilization, and several land management options including tillage, cropping patterns, and nitrogen fertilizer applications (Table 4).

To determine land use change effects, we conducted a simulation ( $\mathrm{S} 2$ in Table 4) in which climate and

TABLE 4. Descriptions of simulations for the terrestrial ecosystems model (TEM) according to transient data sets used for the land cover scenarios.

\begin{tabular}{|c|c|c|c|}
\hline Simulation & Effects examined & Land cover/management scenario & $\begin{array}{l}\text { Atmospheric } \\
\mathrm{CO}_{2}\end{array}$ \\
\hline S1 & control & $\begin{array}{l}\text { both single (no fertilization) and double crops with } \\
\text { conservation tillage }\end{array}$ & variable \\
\hline $\mathrm{S} 2$ & land use change (S1-S2) & all natural vegetation (no management) & variable \\
\hline S3 & $\mathrm{CO}_{2}$ fertilization $(\mathrm{S} 1-\mathrm{S} 3)$ & $\begin{array}{l}\text { both single (no fertilization) and double crops with } \\
\text { conservation tillage }\end{array}$ & constant \\
\hline S4 & tillage $(\mathrm{S} 1-\mathrm{S} 4)$ & $\begin{array}{l}\text { both single (no fertilization) and double crops with no } \\
\text { tillage }\end{array}$ & variable \\
\hline S5 & tillage (S1-S4) & $\begin{array}{l}\text { Both single (no fertilization) and double crops with } \\
\text { conventional tillage }\end{array}$ & variable \\
\hline S6 & cropping pattern (S4-S6) & cropland, all single cropped (no fertilization, no tillage) & variable \\
\hline S7 & $\mathrm{N}$ fertilizer application $(\mathrm{S} 7-\mathrm{S} 6)$ & cropland, all single cropped (optimal fertilization, no tillage) & variable \\
\hline
\end{tabular}




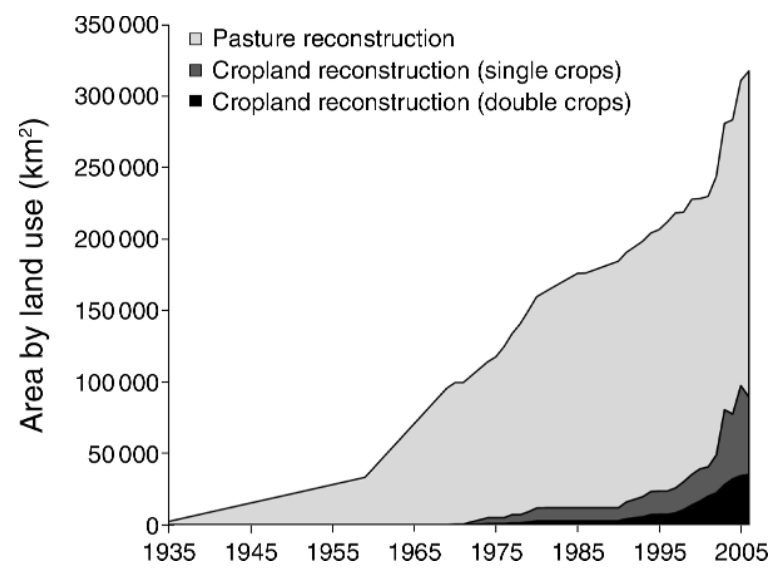

FIG. 2. Reconstruction of croplands (single- and doublecropping patterns) and pasture in Mato Grosso by area, using constraining data from government surveys, census, and remote sensing.

atmospheric chemistry are allowed to change, but the land cover is the same as that found in the year 1901. As our historical land use change data sets indicated that the region was covered by natural vegetation until 1934 , the difference in carbon fluxes and stocks between simulations $\mathrm{S} 1$ and $\mathrm{S} 2$ captures the effects of all land use change in Mato Grosso including interactive effects with other environmental factors and the loss of carbon sequestration potential by replacing natural vegetation with agriculture. To better quantify the effects of land conversions on carbon dynamics, we stratified the net carbon flux based on annual transitions in land cover (33 total transitions, e.g., tropical evergreen forest to pasture, cerrado to single crop, cerradão to cerradão, pasture to single crop, single crop to double crop, double crop to double crop).

To evaluate the effects of $\mathrm{CO}_{2}$ fertilization on carbon dynamics in Mato Grosso, we conducted a simulation (S3 in Table 4) in which climate, ozone, and land use are allowed to change over the historical period, but atmospheric $\mathrm{CO}_{2}$ concentrations remain at the same level found in 1901. The $\mathrm{CO}_{2}$ fertilization effect is then determined by the difference in carbon stocks and fluxes between the $\mathrm{S} 3$ and $\mathrm{S} 1$ simulations. With this approach, we capture both the direct effects of enhanced atmospheric $\mathrm{CO}_{2}$ on carbon dynamics along with any interactive effects of $\mathrm{CO}_{2}$ with other environmental factors.

Running several land use scenarios that include different types of management allows us to evaluate the impacts of each type of management. The conservation tillage used in our control simulation (S1) is the most representative of practices in the region, as it balances the agronomic benefits and drawbacks to no tillage and conventional tillage. To more fully explore the impacts of tillage on the amount of soil organic carbon found in croplands, we conducted one simulation (S4 in Table 4) in which no tillage is assumed to occur on all croplands and another simulation ( $\mathrm{S} 5$ in Table 4) in which conventional tillage (soils are tilled every year) is assumed to occur on all croplands. We do not implement a tillage effect on decomposition under no-till conditions and we implement the tillage effect on decomposition rates every year for conventional tillage rather than every fourth year as for conservation tillage. To assess the potential impacts of cropping patterns on soil carbon dynamics, we conducted a simulation (S6 in Table 4) in which all croplands were assumed to be single cropped. We used single cropping with and without fertilization (S7 and S6, respectively, in Table 4) to evaluate the potential impacts of nitrogen fertilizer application.

\section{RESUlts}

\section{Historical land use reconstruction}

Our reconstruction of land use in Mato Grosso indicates that pastures have historically been the dominant land use in this region (Fig. 2). Pastures first appear in 1934 and there was modest pasture development through 1960. From 1960 to 2000, there were accelerated pasture developments. Croplands emerged in the region in 1971, but their area increased rapidly starting in the late 1990s, as soybean varieties became available for the Amazon, and dramatically increased from 2000. By 2006, >221 $092 \mathrm{~km}^{2}$ were in pasture use and $89533 \mathrm{~km}^{2}$ were in cropland use. We distinguished double-cropping patterns, which appear at large scales in the early 1980s. Of the cropland area in 2006, 54159 $\mathrm{km}^{2}$ were single cropped and $35374 \mathrm{~km}^{2}$ were double cropped.

The cerrado region hosts more of the croplands than the other natural ecosystems, and by 2006, almost $20 \%$ of the cerrado region had been converted to croplands (Galford et al. 2010). Pastures tend to be more spatially disparate, while croplands nucleate around existing croplands (Fig. 3). We did not consider secondary growth as one of the regional land cover and land use trajectories because it has been identified as of minor importance in Mato Grosso (Rudel et al. 2005, Morton et al. 2006), although Fearnside et al. (2009) suggest regrowth may have a large impact on post-clearing carbon stocks.

\section{Historical carbon dynamics in Mato Grosso}

Our simulations show that over the 105 years between 1901 and 2006, Mato Grosso lost 4.8 Pg C, largely due to land clearing for pasture and croplands. Over the same period, these losses were slightly offset by the uptake of $0.3 \mathrm{Pg} \mathrm{C}$ by intact natural ecosystems. The net loss of carbon from land ecosystems in Mato Grosso over the study period was therefore 4.5 Pg C (Fig. 4).

Carbon losses from land use changes were minimal from the 1930s through the 1950s, but steadily increased from the 1960s through 1990s with the expansion of pasture areas and the beginning of the expansion of cropland areas (Fig. 5). The most rapid carbon losses 


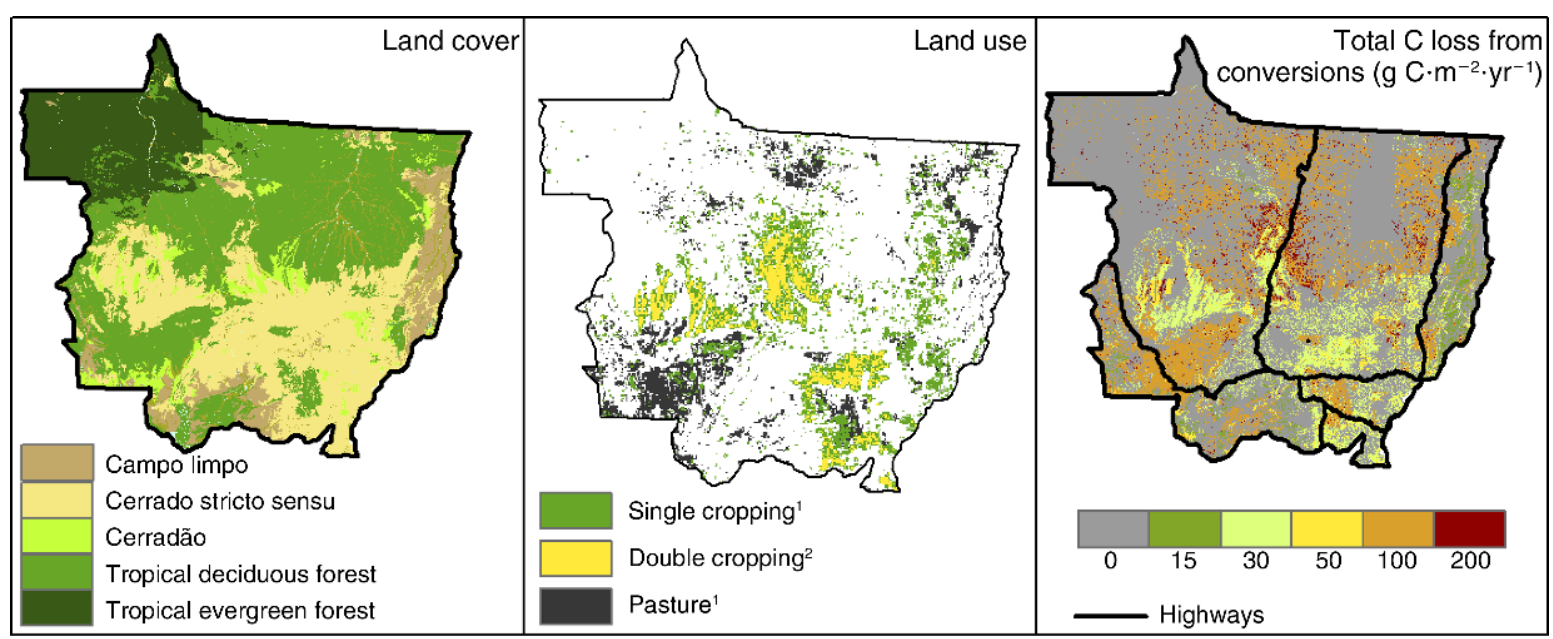

FIG. 3. Potential vegetation cover, land use in 2006, and total carbon lost from land use conversions over the study period. Superscripts in the land use key indicate sources: 1, Galford et al. (2010); 2, Morton et al. (2006, 2009).

from land use change have occurred since 2000. Between 2000 and 2006, annual emissions from land use were on average $146 \mathrm{Tg} \mathrm{C} / \mathrm{yr}$.

For the entire study period, carbon losses from forest clearing accounted for about $80 \%$ or $3.8 \mathrm{Pg} \mathrm{C}$ of the 4.8 $\mathrm{Pg} \mathrm{C}$ lost from Mato Grosso, with most of the rest, $19 \%$ or $0.9 \mathrm{Pg} \mathrm{C}$, lost from the clearing of cerrado. The remaining carbon loss $(\sim 1 \%)$ results from pasture-tocropland transitions.

The clearing of forests and cerrado for pasture were the dominant land use transitions (Fig. 5). Forest clearing for pasture was responsible for $\sim 75 \%$ of the total carbon loss, and the clearing of cerrado for pasture was responsible for approximately another $15 \%$. The direct clearing of forests and cerrado for croplands, a relatively recent phenomenon in Mato Grosso, accounted for $10 \%$. There is a strong spatial relationship evident between the highest rates of carbon loss from forested regions, as well as with areas of agriculture (Fig. 3).

Most of the lost carbon, 4.5 Pg C, came from vegetation cut and burned during clearing or the decay of the resulting wood products. Some vegetation carbon was rapidly oxidized to $\mathrm{CO}_{2}$ by burning and some was more slowly oxidized to $\mathrm{CO}_{2}$ in microbially mediated decay. A much smaller amount came from the decay of soil organic matter following clearing $(0.3 \mathrm{Pg} \mathrm{C})$. For both vegetation and soils, most of this carbon loss comes from forested areas (Fig. 6). Forests have a greater proportion of carbon loss from soils relative to vegetation, as compared to cerrado.

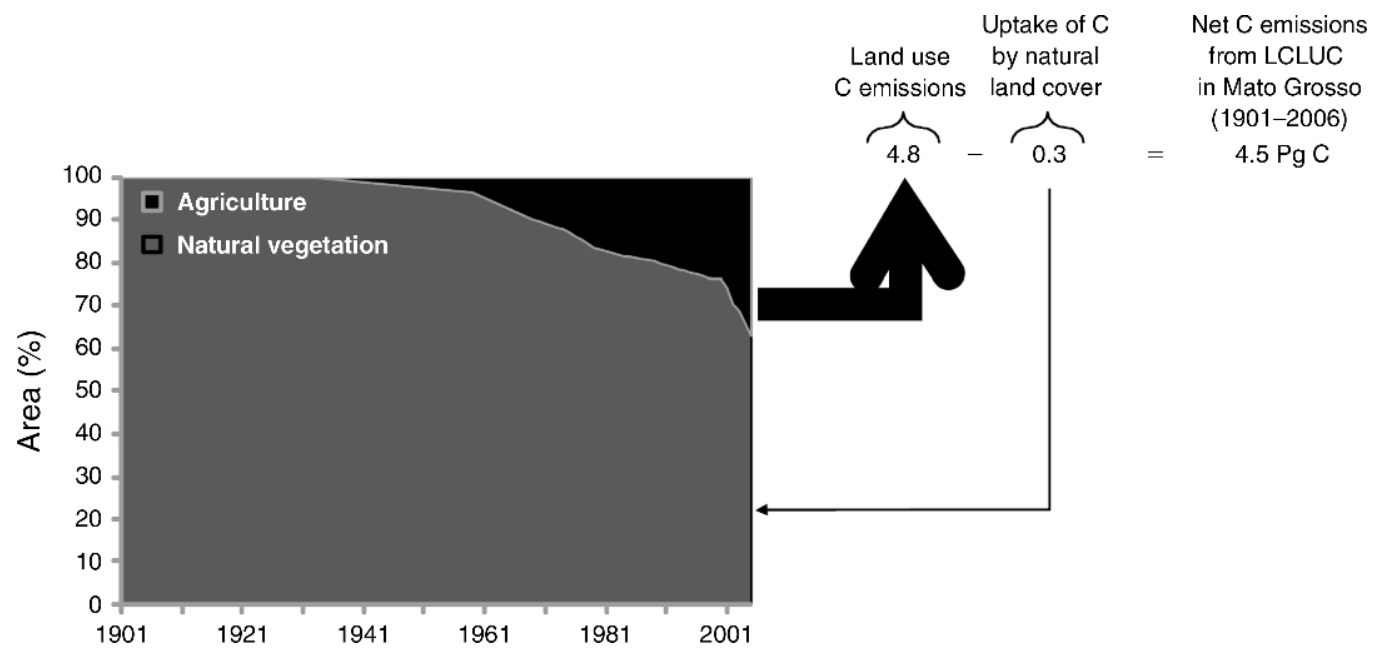

FIG. 4. Carbon emissions from land use and land use change and carbon uptake by intact natural vegetation, including emissions from conversions from natural vegetation to agriculture, transitions between pasture and crop agriculture, and management following clearing in Mato Grasso. The width of the black arrows is related to the magnitude of the carbon flux. LCLUC stands for land cover and land use change. 


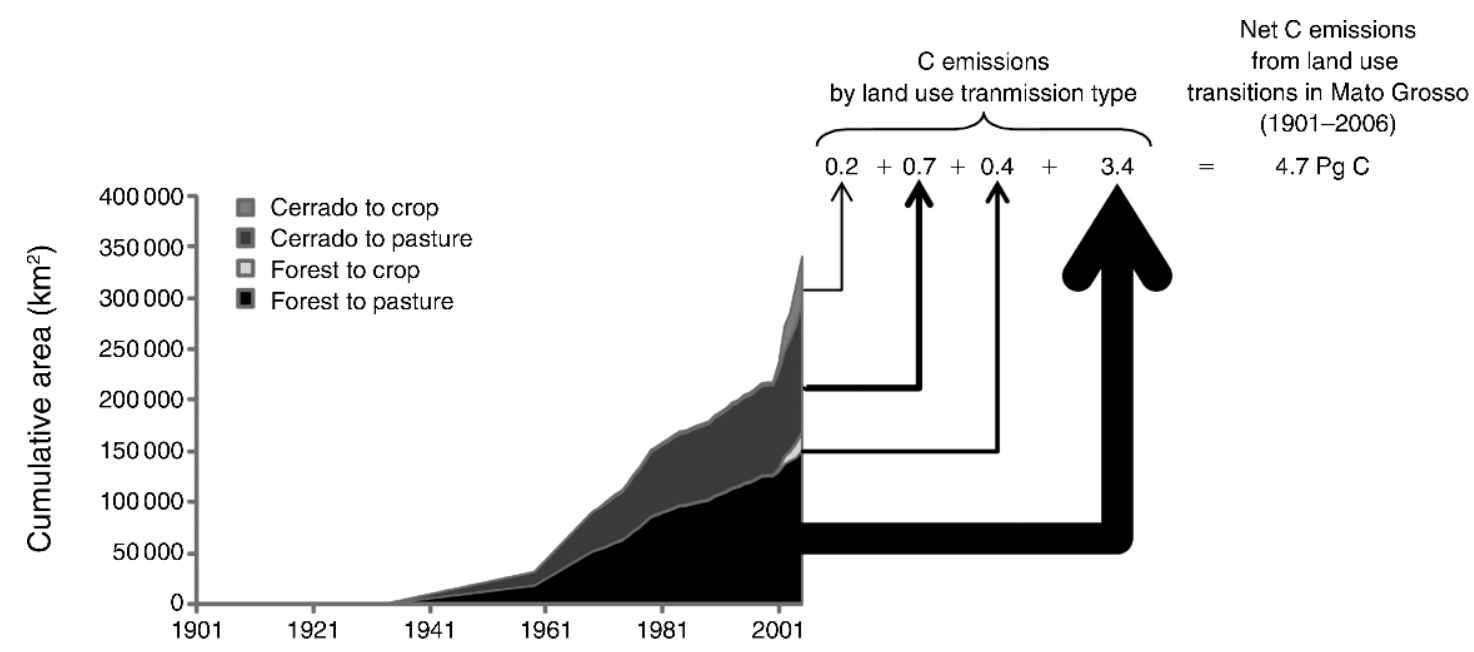

FIG. 5. Land use change carbon emissions by land use transition. The width of the black arrows is related to the magnitude of the carbon flux.

\section{Carbon balance in natural ecosystems}

Starting in 1901 with changing climate and $\mathrm{CO}_{2}$, we find an increase of $0.28 \mathrm{Pg} \mathrm{C}$ in intact natural vegetation. In our simulations, if atmospheric $\mathrm{CO}_{2}$ is held constant ( $\mathrm{S} 3$ in Table 4) over this study period, we find that these natural ecosystems would have lost $0.47 \mathrm{Pg} \mathrm{C}$ instead of gaining carbon. This indicates that $\mathrm{CO}_{2}$ fertilization enhances carbon storage in these intact natural ecosystems by $0.75 \mathrm{Pg} \mathrm{C}$ over the study period. Most of this additional carbon storage occurs in tropical deciduous forests and cerrado stricto sensu, together accounting for $75 \%$ of the carbon sink from $\mathrm{CO}_{2}$ fertilization (Fig. 7).

\section{Carbon dynamics related to pasture and cropland management}

After clearing, we estimate that soils in agricultural systems can either gain or lose carbon. In forest-topasture and cerrado-to-pasture transitions, we simulate a long-term net gain in soil carbon, but this is a minor carbon increase to the large net carbon losses from clearing. For all croplands, we simulate carbon losses from the soils, with the smallest losses associated with conservation tillage and nitrogen fertilization application in double-cropping patterns. Conventional tillage increased carbon losses by $20 \%$. Our estimate of the amount of fertilizer required for croplands, $48 \pm 11 \mathrm{~kg}$ $\mathrm{N} \cdot \mathrm{ha}^{-1} \cdot \mathrm{yr}^{-1}$ (mean $\pm \mathrm{SD}$ ) over the study period, which is within the range of fertilizer doses observed on farms and suggested by field trials (Galford et al. 2010).

\section{DisCUSSION}

Carbon losses from land use changes in Mato Grosso have been the subject of two recent studies in addition to ours. DeFries et al. (2008) estimated carbon emissions using remote sensing to detect fires and process-based biogeochemical modeling of combustion and decay along different land use trajectories (Table 5). For the period 2001-2005, DeFries et al. (2008) estimate $89 \mathrm{Tg}$ $\mathrm{C} / \mathrm{yr}$ is lost. Another study by Fearnside et al. (2009) uses a bookkeeping model to account for combustion, decay, release of graphite particles, carbon storage by replacement biomass, emissions from cattle, and changes in forest methane sources and sinks. That study uses annual deforestation statistics reported by the Brazilian government (INPE 2009b) for 2007, the lowest deforestation year on record $\left(2040 \mathrm{~km}^{2} / \mathrm{yr}\right.$ cleared). To compare to DeFries et al. (2008), we used the Fearnside et al. (2009) emissions rates per unit area with the mean annual deforestation rates reported by INPE (2009b) for the period 2001-2005 (Table 5). This adjusted estimate, based on Fearnside et al. (2009), becomes $113 \mathrm{Tg} \mathrm{C} / \mathrm{yr}$. For the 2001-2005 period, our results show emissions of $163 \mathrm{Tg} \mathrm{C} / \mathrm{yr}$. Considered together, these studies highlight the important differences between assumptions and considerations affecting estimates of carbon emissions.

We understand many of the differences that have caused these variations in carbon emission estimates for Mato Grosso, including biomass estimates, input land use change data set accuracy, biome boundary definitions, and land use change trajectories. Initial biomass estimates account for much of the difference in carbon emission estimates between our study and Fearnside et al. (2009). Our biomass estimates are higher for tropical evergreen forests $(217 \pm 75 \mathrm{Mg} \mathrm{C} / \mathrm{ha}$; mean $\pm \mathrm{SD})$ than the $169 \mathrm{Mg} \mathrm{C}$ /ha reported by Fearnside et al. (2009), but are quite similar for all other natural vegetation classes between the two studies. There may be differences in biome boundaries and land use transitions between our study and the study by DeFries et al. (2008), and, in particular, we included carbon losses from the cerradoto-pasture transition that was not addressed by their study (Table 5). Accuracy from the input land use change remote sensing products is another potential source of error. For example, our work uses land use 
data on croplands that were detected with $85 \%$ accuracy through remote sensing methods that introduce a source of potential error in the results. Our estimates for carbon losses at the time of clearing may exceed actual losses in areas where selective logging occurred. Selective logging typically happens within a few years of deforestation (Asner et al. 2005, 2006) or in areas subjected to wildfires induced by logging or climate-related canopy conditions (Nepstad et al. 2008). These factors highlight the need for better quantification of biomasses across climate gradients.

Mato Grosso is a hot spot for carbon emissions from land use changes in the Legal Amazon, which includes both forest and cerrado. Our annual carbon emissions estimate for Mato Grosso is larger than the Brazilian government's estimates (Ministry of Science and Technology 2006) for forest clearing in the Legal Amazon (117 Tg C/yr), but smaller than the corresponding estimates for land clearing in both forest and cerrado (167 Tg C/yr). The government estimates used PRODES (Programa Despoluição de Bacias Hidrográficas) deforestation detections and estimated forest regrowth through visual interpretation of 44 Landsat satellite images that was then extrapolated to the rest of the biome. In a bookkeeping approach, the government estimates combined the net deforestation with allometric estimates of biomass through field survey data from the RADAMBRASIL project to estimate carbon emissions, a method which Fearnside et al. (2009) points out will overemphasize lower biomass ecosystems and underreport carbon emissions.

Post-clearing, managing agricultural systems to minimize soil $\mathrm{C}$ losses or increase carbon sequestration in soils is important for sustainable development. Our findings suggest that best practices from management of both pastures and crops can minimize further soil carbon losses or actually promote a small carbon sink and are supported by field studies (Moraes et al. 1996, Neill et al. 1997, Bayer et al. 2006, Jantalia et al. 2007, Carvalho et al. 2009). We find that conservation tillage with nitrogen fertilizer for the second crop in a double-cropping system promotes the largest amount of carbon storage in soils. The application of $\mathrm{N}$ fertilizer increases soil carbon stocks through increased crop productivity and returns of crop residue to soils. Conservation tillage decreases some of the negative impacts of tillage; decomposition rates increase with tillage, as tillage introduces residues into the soil where there are often more favorable conditions for decomposition (Karlen and Cambardella 1996, Six et al. 1999), promotes soil microbial activity through aeration (Kladivko 2001), and disrupts soil aggregates that otherwise protect carbon from microorganisms (Karlen and Cambardella 1996). There are other benefits of conservation tillage or no tillage, such as reduced runoff and soil erosion, that are not considered in this paper but are important for both agricultural and environmental sustainability (Lal and Kimble 1997).
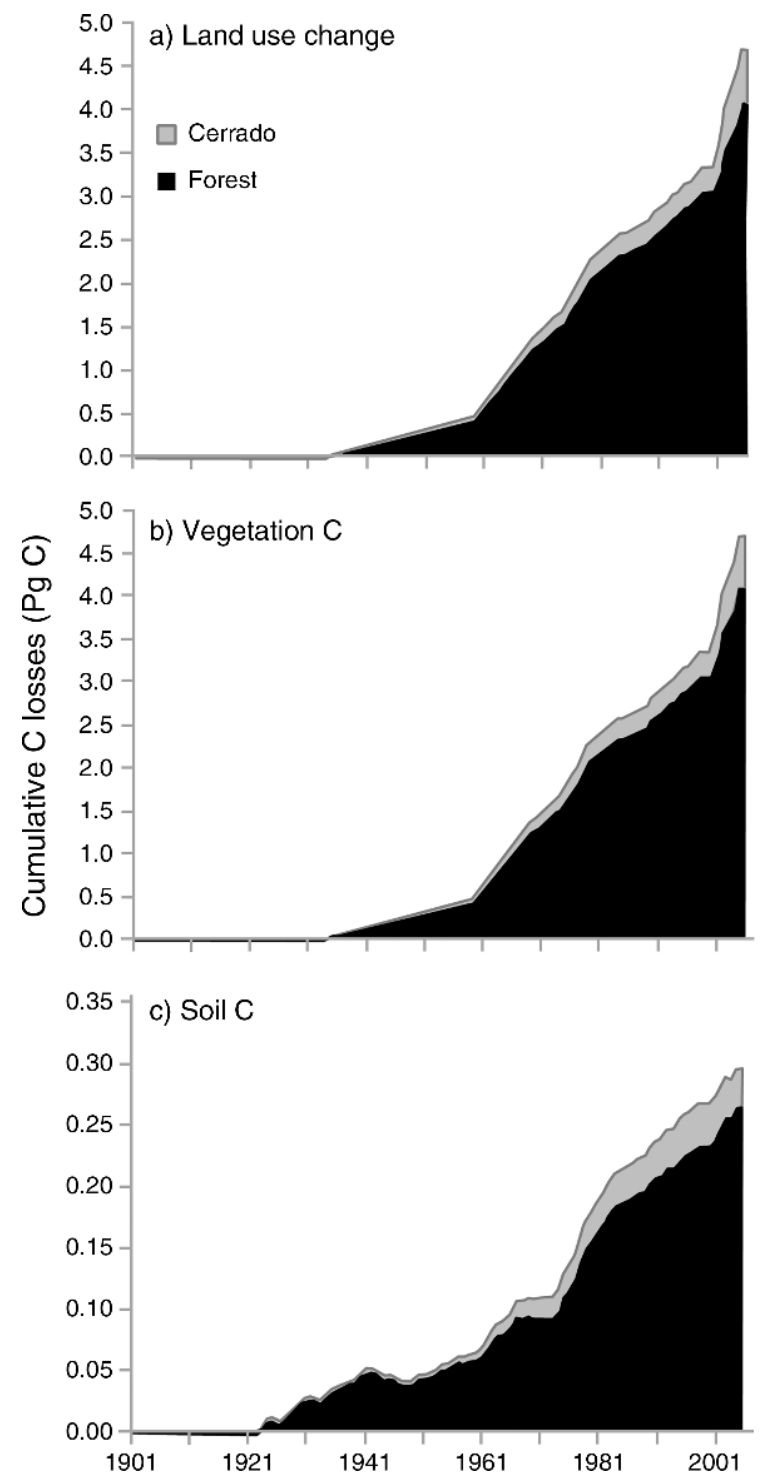

Fig. 6. (a) Cumulative losses in carbon stocks from land use change, grouped by forest- and cerrado-type biomes. (b, c) Cumulative carbon losses from (b) vegetation carbon and (c) soil carbon.

Recent studies (Laurance et al. 2009) suggest that increasing atmospheric $\mathrm{CO}_{2}$ is increasing forest aboveground biomass in the Amazon. Laurance et al. (2009) observed a $4 \%$ growth in forest plots over a period of 22 years. They suggest this increase in growth is due to a $\mathrm{CO}_{2}$ fertilization effect. The TEM model predicts a smaller effect of $\mathrm{CO}_{2}$ fertilization in Mato Grosso, $\sim 1 \%$ over the 20th century, an increase that is difficult to measure in the field. Previous biogeochemical modeling studies in the Amazon (e.g., Potter et al. 2009) have focused on short timescales of a few years, over which $\mathrm{CO}_{2}$ fertilization is assumed to have no effect, but this work shows that increasing atmospheric $\mathrm{CO}_{2}$ levels may 


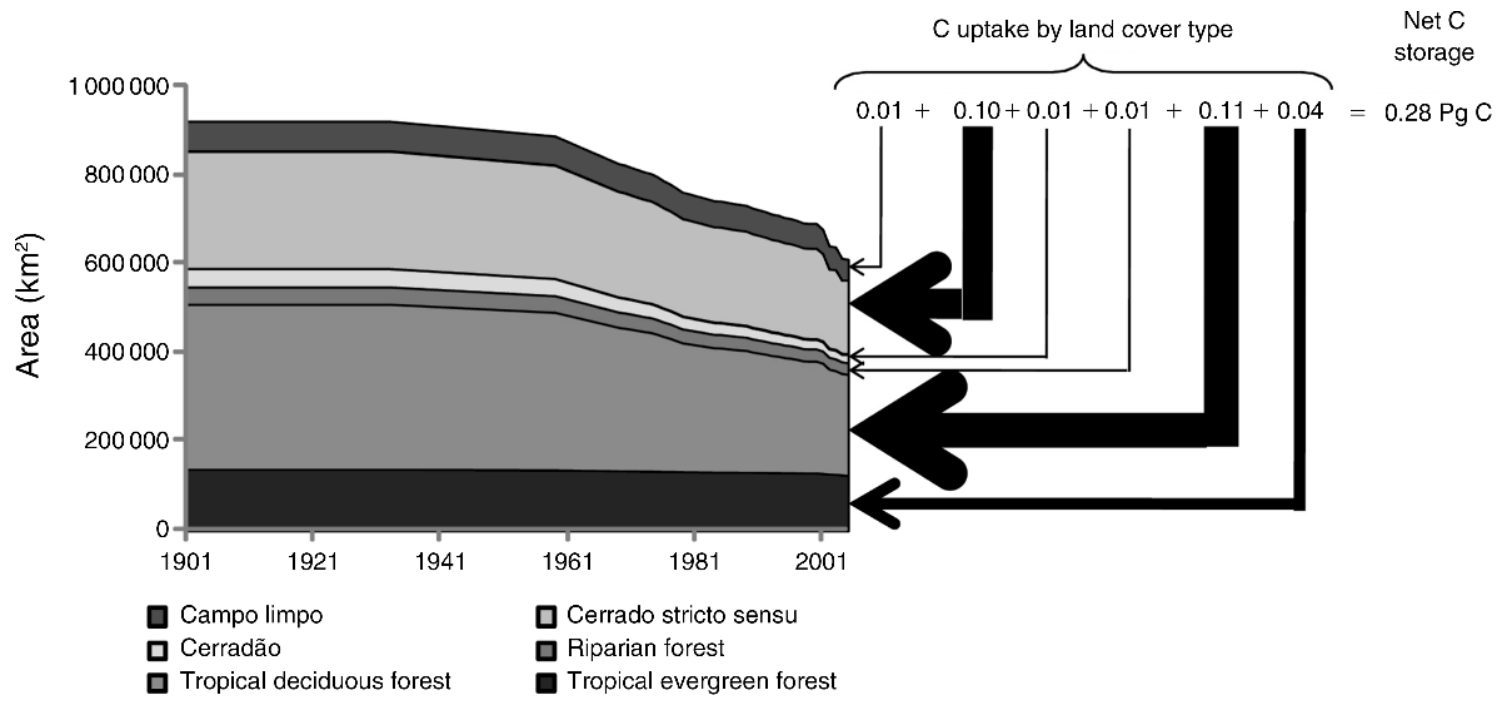

FIG. 7. Carbon uptake by intact natural vegetation, shown by land cover class. The width of the black arrows is related to the magnitude of the carbon flux.

have long-term impacts on carbon storage in natural vegetation.

Going beyond contemporary and historical carbon budgets, we estimate foregone carbon sequestration from the original land cover that has been lost due to land use changes. In the absence of any land use from 1901 to 2006, our analysis (S2 in Table 4) suggests carbon stocks in Mato Grosso would have increased $2.7 \%$, representing a carbon sink of $0.5 \mathrm{Pg} \mathrm{C}$. Thus, land use change has reduced the capacity of Mato Grosso ecosystems to sequester carbon by $0.2 \mathrm{Pg} \mathrm{C}$ (i.e., $0.5 \mathrm{Pg}$ $\mathrm{C}$ described above minus the $0.3 \mathrm{Pg} \mathrm{C}$ sequestered in residual natural lands; see Fig. 7) in addition to causing a net loss of $4.5 \mathrm{Pg} \mathrm{C}$ over the historical period from 1901 to 2006.

For the 2000-2006 period, Mato Grosso carbon emissions as estimated by us account for between $1 \%$ and $2 \%$ of recent estimates of land use change carbon emissions, which are on the order of $1.5 \mathrm{Pg} \mathrm{C} / \mathrm{yr}$
(Canadell et al. 2007). The uncertainty in pan-tropical carbon emission estimates could be reduced by applying the coupled remote sensing and modeling approach presented here in a wide survey across the tropics. Critical steps in applying this linked approach involve reducing uncertainty surrounding these estimates. This could be achieved by increasing field data sets for training and validation, remote sensing detections of land use, and by ecological field studies across environmental gradients in major biomes that could provide useful information in model parameterization and calibration while reducing uncertainties in the spatial variation of biomass estimates (Fearnside et al. 2009).

Our analysis suggests that emissions from Mato Grosso are larger than Brazil's fossil fuel emissions. We estimate that land clearing in Mato Grosso releases an average of $146 \mathrm{Tg} \mathrm{C} / \mathrm{yr}$ since 2000, which is greater than Brazil's current fossil fuel emissions (89 Tg C/yr; Marland et al. 2008) and suggests the actual net

TABle 5. Comparison of carbon emission estimates for Mato Grosso between three studies overlapping from 2001 to 2005.

\begin{tabular}{|c|c|c|c|c|c|}
\hline \multirow[b]{2}{*}{ Model } & \multicolumn{4}{|c|}{ Net average area cleared, $2001-2005\left(\mathrm{~km}^{2} / \mathrm{yr}\right)$} & \multirow{2}{*}{$\begin{array}{c}\text { Net annual } \\
\text { average emissions, } \\
\text { 2001-2005 (Tg C/yr) }\end{array}$} \\
\hline & $\begin{array}{l}\text { Forest } \rightarrow \\
\text { pasture, crop }\end{array}$ & $\begin{array}{l}\text { Cerrado } \rightarrow \\
\text { pasture }\end{array}$ & $\begin{array}{l}\text { Cerrado } \rightarrow \\
\quad \text { crop }\end{array}$ & $\begin{array}{l}\text { Pasture } \rightarrow \\
\quad \text { crop }\end{array}$ & \\
\hline Defries et al. (2008) & 7371 & $\cdots$ & 4284 & 2862 & 84 \\
\hline $\begin{array}{l}\text { INPE }(2009 b) \text {, Fearnside } \\
\text { et al. }(2009) \dagger\end{array}$ & 8991 & $\cdots$ & $\cdots$ & $\cdots$ & 113 \\
\hline This study & 6223 & 7599 & 2338 & 6577 & 163 \\
\hline
\end{tabular}

Notes: Different models result in a range of carbon emission estimates for each land cover and land use transition. A comparison of the models and their estimates shows that methods have a large effect on estimated emission. The data presented here include only the state of Mato Grosso for the years 2001-2005 for comparison purposes. DeFries et al. (2008) is a process-based cohort model with combustion and decay; INPE (2009b)/Fearnside et al. (2009) is a bookkeeping model with combustion, decay, graphitic particle release, carbon storage from replacement biomass, emissions from cattle, and loss of forest methane sources and sinks; this study uses a process-based cohort model with combustion (pasture and cropland clearings), decay (process-based model distinguishes heterotrophic and autotrophic respiration, including long-term decay of slash and wood products), carbon dynamics for agricultural vegetation, and soils simulated with a process-based model.

$\dagger$ Assumes the same net emissions on a per-area basis as Fearnside et al. (2009) calculate for 2007-2008, here adjusted for higher deforestation rates from 2001 to 2005. 
emissions from Brazil are much higher than solely the fossil fuel and cement emissions typically considered. In fact, several studies have suggested that total emissions from a country should be the sum of fossil fuel, cement, and deforestation emissions, which might raise Brazil's global rank for top emitting countries (Cerri et al. 2004, 2007, Boden et al. 2009). In addition, we estimate an average contemporary (since 2000) carbon sink in intact natural land cover of $28.4 \mathrm{Tg} \mathrm{C} / \mathrm{yr}$ in Mato Grosso. The net carbon budget for this deforestation hot spot in the Amazon is a strong argument for including both land use change emissions (carbon loss) and uptake by intact natural vegetation (carbon sink) along with fossil fuel emissions when calculating national-scale carbon emissions, not just for Brazil but for all countries. This is the type of detailed information necessary to support policy decisions, such as the United Nations Framework Convention on Climate Change (UNFCCC) Programme on Reducing Emissions from Deforestation and Degradation (REDD).

\section{CONCLUSIONS}

The analyses we present here represent a significant step forward in integrating historical land use with modern land use change quantified from remotely sensed data and using these as critical boundary conditions on biogeochemical modeling. Through this process, we quantify changes in carbon stocks, including the effects of increased atmospheric $\mathrm{CO}_{2}$. Thus this analysis moves beyond previous studies that focus on natural systems or emissions from conversions and accommodate the full dynamic processes of land cover change and land management practices.

This work shows that the historical role of land use change has made serious contributions to the net carbon emissions from this region, but that recent, rapid changes in land use primarily through clearing of forests has increased the annual emissions greatly. We find that intact natural ecosystems have been a continuing net sink for carbon, but if historical land use change is any indicator of the future, future deforestation could seriously reduce this carbon sink, as well as release carbon currently stored in natural vegetation.

It is clear that some agricultural expansion will continue (Soares-Filho et al. 2006). Our evaluation of greenhouse gas emissions from land use change in this region shows a way forward on future mitigation of global warming. The role of this region in mitigation depends on reducing emissions from land cover and land use change, conserving intact natural vegetation that is both a carbon reservoir and an active carbon sink, and following best management practices for both pasture and croplands that minimize further carbon losses or actually promote a small carbon sink.

\section{ACKNOWLEDGMENTS}

This work was supported by NASA's Earth and Space Science Fellowship (G. L. Galford) and NASA's Large-Scale Biosphere-Atmosphere Experiment in Amazonia (grant num- ber NNG06GE20A). NCEP Reanalysis data were provided by the NOAA/OAR/ESRL PSD, Boulder, Colorado, USA.

\section{Literature Cited}

Asner, G. P., E. N. Broadbent, P. J. C. Oliveira, M. Keller, D. E. Knapp, and J. N. M. Silva. 2006. Condition and fate of logged forests in the Brazilian Amazon. Proceedings of the National Academy of Sciences USA 103:12947-12950.

Asner, G. P., D. E. Knapp, E. N. Broadbent, P. J. C. Oliveira, M. Keller, and J. N. Silva. 2005. Selective logging in the Brazilian Amazon. Science 310:480-482.

Balesdent, J., C. Chenu, and M. Balabane. 2000. Relationship of soil organic matter dynamics to physical protection and tillage. Soil and Tillage Research 53(3-4):215-230.

Batjes, N., M. Bernoux, and C. Cerri. 2004. Soil data derived from SOTER for studies of carbon stocks and change in Brazil. Version 1.0. International Soil Reference and Information Center, World Soil Information, Wageningen, The Netherlands.

Bayer, C., L. Martin-Neto, J. Mielniczuk, A. Pavinato, and J. Dieckow. 2006. Carbon sequestration in two Brazilian cerrado soils under no-till. Soil and Tillage Research 86:237-245.

Boden, T. A., G. Marland, and R. J. Andrew. 2009. Global, regional and national fossil-fuel $\mathrm{CO}_{2}$ emissions. Carbon Dioxide Information Analysis Center, U.S. Department of Energy, Oak Ridge National Laboratory, Oak Ridge, Tennessee, USA.

Canadell, J. G., C. Le Quere, M. R. Raupach, C. B. Field, E. T. Buitenhuis, P. Ciais, T. J. Conway, N. P. Gillett, R. A. Houghton, and G. Marland. 2007. Contributions to accelerating atmospheric $\mathrm{CO}_{2}$ growth from economic activity, carbon intensity and efficiency of natural sinks. Proceedings of the National Academy of Sciences USA 104:18866-18870.

Carvalho, J. L. N., C. E. P. Cerri, B. J. Feigel, M. Piccolo, V. P. Godinho, and C. C. Cerri. 2009. Carbon sequestration in agricultural soils in the cerrado region of the Brazilian Amazon. Soil and Tillage Research 103:342-349.

Castro, E. A., and J. B. Kauffman. 1998. Ecosystem structure in the Brazilian cerrado: a vegetation gradient of aboveground biomass, root mass and consumption by fire. Journal of Tropical Ecology 14(3):263-283.

Cerri, C. C., M. Bernoux, C. E. P. Cerri, and C. Feller. 2004. Carbon cycling and sequestration opportunities in South America: the case of Brazil. Soil Use and Management $20: 248-254$.

Cerri, C. E. P., G. Sparovek, M. Bernoux, W. E. Easterling, J. M. Melillo, and C. C. Cerri. 2007. Tropical agriculture and global warming: impacts and mitigation options. Scientia Agricola 64:83-99.

Conservation International. 2008. Cerrado. Biodiversity hotspots. 〈http://www.biodiversityhotspots.org

DeFries, R., D. Morton, G. van der Werf, L. Giglio, G. J. Collatz, J. Randerson, R. A. Houghton, P. Kasibhatla, and Y. E. Shimabukuro. 2008. Fire-related carbon emissions from land-use transitions in southern Amazonia. Geophysical Research Letters 35:L22705.

Etheridge, D. M., L. P. Steele, R. L. Langenfelds, R. J. Francey, J. M. Barnola, and V. I. Morgan. 1996. Natural and anthropogenic changes in atmospheric $\mathrm{CO}_{2}$ over the last 1000 years from air in Antarctic ice and firn. Journal of Geophysical Research-Atmospheres 101(D2):4115-4128.

FAO [Food and Agricultural Organization]. 2006. Global Forest Resources Assessment 2005: progress towards sustainable forest management. Food and Agricultural Organization of the United Nations, Rome, Italy.

Fearnside, P. M., C. A. Righi, P. M. L. A. Graça, E. W. H. Keizer, C. C. Cerri, E. M. Nogueira, and R. I. Barbosa. 2009. Biomass and greenhouse-gas emissions form land-use change in Brazil's Amazonian "arc of deforestation": the states of 
Mato Grosso and Rondônia. Forest Ecology and Management 258:1968-1978.

Felzer, B., D. W. Kicklighter, J. M. Melillo, C. Wang, Q. Zhuang, and R. Prinn. 2004. Effects of ozone on net primary production and carbon sequestration on the conterminous United States using a biogeochemistry model. Tellus 56B:230-248.

Felzer, B. J., J. Reilly, J. M. Melillo, D. W. Kicklighter, C. Wang, R. Prinn, and Q. Zhuang. 2005. Future effects of ozone on carbon sequestration and climate change policy using a global biogeochemical model. Climatic Change 73:345-373.

Fundação Agrisus. 2006. Rally da Safra 2006: Situação do plantio direto e da integração lavoura-pecuária no Brasil. Agroconsult, Florianópolis, Brazil.

Galford, G. L., J. M. Melillo, J. F. Mustard, C. E. P. Cerri, and C. C. Cerri. 2010. The Amazon frontier of land-use change: croplands and consequences for greenhouse gas emissions. Earth Interactions 14, in press.

Grace, J., J. Lloyd, J. McIntyre, A. Miranda, P. Meri, H. Miranda, C. Nobre, J. Monteith, J. Massheder, I. Wright, and J. Gash. 1995. Carbon dioxide uptake by an undisturbed tropical rain forest in southwest Amazonia, 1992 to 1993. Science 270:778-780.

Hansen, M. C., et al. 2008. Humid tropical forest clearing from 2000 to 2005 quantified by using multitemporal and multiresolution remotely sensed data. Proceedings of the National Academy of Sciences USA 105:9439-9444.

Houghton, R. A., J. E. Hobbie, J. M. Melillo, B. Moore, B. J. Peterson, G. R. Shaver, and G. M. Woodwell. 1983. Changes in the carbon content of terrestrial biota and soils between 1860 and 1980: a net release of $\mathrm{CO}_{2}$ to the atmosphere. Ecological Monographs 53:235-262.

INPE [International Network of Philosophers of Education]. 2009a. Sistema DETER. 〈http://www.obt.inpe.br/deter/>

INPE [International Network of Philosophers of Education]. 2009b. Projecto PRODES: monitoramento da floresta Amazônica Brasileira por satélite. 〈http://www.obt.inpe.br/ prodes $/\rangle$

Jacobsen, A. R., S. E. M. Fletcher, N. Gruber, J. L. Sarmiento, and M. Gloor. 2007. A joint atmosphere-ocean inversion for surface fluxes of carbon dioxide. 1. Methods and global-scale fluxes. Global Biogeochemical Cycles 21. [doi: 10.1029/ 2005GB002556]

Jantalia, C. P., D. V. S. Resck, B. J. R. Alves, L. Zotarelli, S. Urquiaga, and R. M. Boddey. 2007. Tillage effect on C stocks of a clayey Oxisol under a soybean-based crop rotation in the Brazilian cerrado region. Soil and Tillage Research 95:97-109.

Justice, C. O. 1998. The moderate resolution imaging spectroradiometer (MODIS): land remote sensing for global change research. IEEE Transactions on Geosciences and Remote Sensing 36:1228-1249.

Kalnay, E., et al. 1996. The NMC/NCAR 40-Year Reanalysis Project. Bulletin of the American Meteorology Society 77:437-471.

Karlen, D. L., and C. A. Cambardella. 1996. Conservation strategies for improving soil quality and organic matter storage. Pages 395-420 in M. R. Carter and B. A. Stewart, editors. Structure and organic matter storage in agricultural soils. Advances in Soil Science. CRC Press,Boca Raton, Florida, USA.

Keeling, C. D., S. C. Piper, R. B. Bacastow, M. Wahlen, T. P. Whorf, M. Heimann, and H. A. Meijer. 2005. Atmospheric $\mathrm{CO}_{2}$ and ${ }^{13} \mathrm{CO}_{2}$ exchange with the terrestrial biosphere and oceans from 1978 to 2000: observations and carbon cycle implications. Pages 83-113 in J. R. Ehleringer, T. E. Cerling, and M. D. Dearing, editors. A history of atmospheric $\mathrm{CO}_{2}$ and its effects on plants, animals, and ecosystems. Springer Verlag, New York, New York, USA.
Keys, E., and W. H. McConnell. 2005. Global change and the intensification of agriculture in the tropics. Global Environmental Change 15:320-337.

Kladivko, E. J. 2001. Tillage systems and soil ecology. Soil and Tillage Research 61:61-76.

Klink, C. A., and R. B. Machado. 2005. Conservation of the Brazilian cerrado. Conservation Biology 19:707-713.

Lal, R., and J. M. Kimble. 1997. Conservation tillage for carbon sequestration. Nutrient Cycling in Agroecosystems 49:243-253.

Laurance, S. G. W., W. F. Laurance, H. E. M. Nasciemento, A. Andrade, P. M. Fearnside, E. R. G. Rebello, and R. Condit. 2009. Long-term variation in Amazon forest dynamics. Journal of Vegetation Science 20:323-333.

Malhi, Y., A. D. Nobre, J. Grace, B. Kruijt, M. G. Pereira, A. Culf, and S. Scott. 1998. Carbon dioxide transfer over a Central Amazonian rain forest. Journal of Geophysical Research 103:31593-31612.

Marland, G., T. A. Boden, and R. J. Andres. 2008. Global, regional, and national $\mathrm{CO}_{2}$ emissions. Carbon Dioxide Information Analysis Center, Oak Ridge National Laboratory, U.S. Department of Energy, Oak Ridge, Tennessee, USA.

McGuire, A. D., J. M. Melillo, L. A. Joyce, D. W. Kicklighter, A. L. Grace, B. Moore III, and C. J. Vorosmarty. 1992. Interactions between carbon and nitrogen dynamics in estimating net primary productivity for potential vegetation in North America. Global Biogeochemical Cycles 6:101-124.

McGuire, A. D., J. M. Melillo, and D. Kicklighter. 2001. Carbon balance of the terrestrial biosphere in the twentieth century: analyses of $\mathrm{CO}_{2}$, climate and land-use effects with four process-based ecosystem models. Global Biogeochemical Cycles 15:183-206.

Mello, F. 2007. Estimativas dos estoques de carbono dos solos nos Estados de Rondônia e Mato Grosso anteriores à intervenção antrópica. Master's dissertation. Universidade de São Paulo, Piracicaba, Brazil.

Ministry of Science and Technology. 2006. Carbon dioxide emissions and removals from forest conversion and abandonment of managed lands. First Brazilian Inventory of Anthropogenic Greenhouse Gas Emissions, Brazilian Ministry of Science and Technology, Brasilia, Brazil.

Miranda, A., H. S. Miranda, J. Lloyd, J. Grace, R. J. Francey, J. A. McIntyre, P. Meir, P. Riggan, R. Lockwood, and J. Brass. 2008. Fluxes of carbon, water and energy over Brazilian cerrado: an analysis using eddy covariance and stable isotopes. Plant, Cell and Environment 20:315-328.

Mitchell, T., T. R. Carter, P. D. Jones, M. Hulme, and M. New. 2004. A comprehensive set of high-resolution grids of monthly climate for Europe and the globe: the observed record (1901-2000) and 16 scenarios (2001-2100). Working Paper 55. Tyndall Center for Climate Change, University of East Anglia, Norwich, UK.

Moraes, J. F. L., B. Volkoff, C. C. Cerri, and M. Bernoux. 1996. Soil properties under Amazon forest and changes due to pasture installation in Rondônia, Brazil. Geoderma 70: 63-81.

Morton, D. C., R. DeFries, J. Randerson, L. Giglio, W. Schroeder, and G. van der Werf. 2008. Agricultural intensification increases deforestation fire activity in Amazonia. Global Change Biology 14:2262-2275.

Morton, D., R. DeFries, and Y. E. Shimabukuro. 2010. Cropland expansion in cerrado and transition forest ecosystems: quantifying habitat loss from satellite-based vegetation phenology. In C. A. Klink, editor. Cerrado land use and conservation: advanced applied biodiversity science. Conservation International, Washington, D.C., USA, in press.

Morton, D. C., R. S. DeFries, Y. E. Shimbukuro, L. O. Anderson, E. Arai, F. d. B. Espirito-Santo, R. Freitas, and J. Morisette. 2006. Cropland expansion changes deforestation 
dynamics in the southern Brazilian Amazon. Proceedings of the National Academy of Sciences USA 103:14637-14641.

Myers, N., R. A. Mittermeier, C. G. Mittermeier, G. A. B. d. Fonseca, and J. Kent. 2000. Biodiversity hotspots for conservation priorities. Nature 403:853-858.

National Geophysical Data Center (NGDC). 1994. TerrainBase. Version 1.1. Five-minute digital terrain model data. National Geophysical Data Center, Boulder, Colorado, USA.

Neill, C., B. Fry, J. M. Melillo, P. A. Stuedler, C. C. Cerri, J. F. L. Moraes, M. C. Piccolo, and M. Brito. 1997. Soil organic matter stocks following deforestation for pasture in the southwestern Brazilian Amazon. Ecological Applications $7: 1216-1225$.

Nepstad, D. C., C. M. Stickler, B. Soares-Filho, and F. Merry. 2008. Interactions among Amazon land-use, forests and climate: prospects for a near-term forest tipping point. Philosophical Transactions of the Royal Society B 27:1 737-1746

New, M., D. Lister, M. Hulme, and I. Makin. 2002. A highresolution data set of surface climate over global land areas. Climate Research 21:1-25.

Phillips, O., Y. Malhi, N. Higuchi, W. F. Laurance, P. V. Núñez, R. M. Vásquez, S. G. Laurance, L. V. Ferreira, M. Stern, S. Brown, and J. Grace. 1998. Changes in the carbon balance of tropical forests: evidence from long-term plots. Science 282:439-442.

Potter, C., S. Klooster, A. Huete, V. Genovese, M. Bustamante, L. G. Ferreira, R. C. de Oliveira, Jr., and R. Zepp, editors. 2009. Terrestrial carbon sinks in the Brazilian Amazon and Cerrado region predicted from MODIS satellite data and ecosystem modeling. Biogeosciences Discussions 6:947-969.

Raich, J. W., E. B. Rastetter, J. M. Melillo, D. W. Kicklighter, P. A. Steudler, B. J. Peterson, A. L. Grace, B. Moore III, and C. J. Vorosmarty. 1991. Potential net primary productivity in South America: application of a global model. Ecological Applications 1:399-429.

Ramankutty, N., H. K. Gibbs, F. Achard, R. DeFries, J. A. Foley, and R. A. Houghton. 2007. Challenges to estimating carbon emissions from tropical deforestation. Global Change Biology 13:51-66.

Rudel, T. K., O. Coomes, E. Moran, A. Angelsen, F. Achard, E. Lambin, and J. Xu. 2005. Forest transitions: towards an understanding of global land use change. Global Environmental Change 14(4):23-31.

Saleska, S., et al. 2003. Carbon in Amazon forests: unexpected seasonal fluxes and disturbance losses. Science 302:15541557.

Schimel, D. 2007. Carbon cycle conundrums. Proceedings of the National Academy of Sciences USA 104:18353-18354.

SEPLAN-MT [Secretaria de Estado de Planejamento e Coordenação Geral do Mato Grosso]. 2007. Zoneamento sócio economic ecológico do estada do Mato Grosso. Secretaria de Estado de Planejamento e Coordenação Geral do Mato Grosso. 〈http://www.seplan.mt.gov.br〉

SIDRA [Sistema IGBE de Recuperação Automática]. 2009a. Censo Agropecuário. Sistema Instituto Brasileiro de Geografia e Estatística (IGBE) de Recuperação Automática. $\langle$ http://www.sidra.ibge.gov.br/bda/〉

SIDRA [Sistema IGBE de Recuperação Automática]. $2009 b$. Produção Agrícola Municipal. Sistema Instituto Brasileiro de Geografia e Estatística (IGBE) de Recuperação Automática. $\langle$ http://www.sidra.ibge.gov.br/bda/〉

Six, J., E. T. Elliott, and K. Paustian. 1999. Aggregate and soil organic matter dynamics under conventional and no-tillage systems. Soil Science Society of America Journal 63:1350 1358.

Soares-Filho, B. S., D. C. Nepstad, L. M. Curran, G. C. Cerqueira, R. A. Garcia, C. A. Ramos, E. Voll, A. McDonald, P. Lefebvre, and P. Schlesinger. 2006. Modelling conservation in the Amazon basin. Nature 440:520-523.

Stephens, B. B., et al. 2007. Weak northern and strong tropical land carbon uptake from vertical profiles of atmospheric $\mathrm{CO}_{2}$. Science 316:1732-1735.

Tian, H., J. M. Melillo, D. W. Kicklighter, S. Pan, J. Liu, A. D. McGuire, and B. Moore III. 2003. Regional carbon dynamics in monsoon Asia and its implications for the global carbon cycle. Global and Planetary Change 37:201-217.

\section{APPENDIX}

Creating historical land use reconstructions for Mato Grosso, Brazil (1901-2006) (Ecological Archives A021-038-A1). 